\title{
I. Observations on the crag, and on the fallacies involved in the present system of classification of tertiary deposits
}

Edward Charlesworth Esq. F.G.S.

To cite this article: Edward Charlesworth Esq. F.G.S. (1837) I. Observations on the crag, and on the fallacies involved in the present system of classification of tertiary deposits, Philosophical Magazine Series 3, 10:58, 1-9, DOI: 10.1080/14786443708649060

To link to this article: $h$ ttp://dx.doi.org/10.1080/14786443708649060

曲 Published online: 01 Jun 2009.

Submit your article to this journal $[\pi$

Џll Article views: 2

Q View related articles $\llbracket$ 
T H E

\title{
LONDON AND EDINBURGH
}

\section{PHILOSOPHICAL MAGAZINE}

\author{
A N D \\ JOURNAL OF SCIENCE. \\ [THIRD SERIES.] \\ $J A N U A R Y 1837$.
}

I. Observations on the Crag, and on the Fallacies involved in the present System of Classification of Tertiary Deposits. By Edward Charleswor'Th, Esq., F.G.S., \&.c.*

I DID not venture to propose a separation of the marine 1 deposits above the London Clay in Suffolk, until I considered myself in possession of something more than merely conjectural evidence to justify my division of these fossiliferous strata. That the immense accumulation of testaceous reliquiæ forming the Crag might in some places be seen to be separated from the subjacent beds of clay by a deposit the characters of which did not accord with the general aspect of either of these formations, was a statement involving mere personal observation, and which could therefore at any time be readily refuted or confirmed. But that this coralliferous stratum should be looked upon as holding an intermediate place not only in geological position, but in age, when considered in relation to the beds above and beneath it, was suggesting a notion which appeared to me so far admissible, that its adoption or rejection would entirely depend upon the results attending continued investigation. Anticipating the nature of the objections which I thought might probably be urged against my views, I endeavoured, in my first memoirt, to show that there were strong grounds for believing that the apparent agreement between the organic remains of the Coralline Crag

* Communicated by the Author.

† See Lond. and Edinb. Phil. Mag. for August 1835 : vol. vii. p. 81.

Third Series. Vol. 10. No. 58. Jan. 1837. 
and the superior beds, depended upon the abrasion or natural degradation of one deposit during the formation of the other. I then referred to the large proportion of Red Crag fossils which M. Deshayes had identified with species now known to inhabit the German Ocean ( 40 per cent.): consequently, if my idea of the removal of the fossils from an older to a more recent bed were disputed altogether, the number common to the two crag series would at any rate indicate no nearer approximation of the periods during which these Testacea existed than that established by M.Deshayes between those of the red crag and the Mollusca of our present seas. Under these circumstances, it was certainly with some degree of surprise that I found Mr. Lyell opposing the opinion I had advanced, upon no other ground than that of this very occurrence of analogons species in the two deposits*.

To say nothing of those Sicilian strata, which contain ninety-five per cent. of existing species, it is palpably evident that if a per centage of analogous forms, to the amount of thirty or forty, place in one and the same geological period the races of organized beings occurring in rocks naturally separated by superposition and mineral character, by the same line of reasoning must the red crag, in common with all the other pliocene deposits, be looked upon, geologically speaking, as part and parcel of the formations now going forward in the adjacent seas, although these very deposits have been referred to a distinct epoch by Mr. Lyell from the very circumstance of their containing 40 per cent. of existing species. Paradoxical as it may appear, the facts which in one instance are made use of to prove the wide interval which has elapsed between the deposition of certain marine strata, are on another occasion brought forward to establish diametrically opposite conditions. Thus a division called older pliocene is made for those beds which contain so few as 40 per cent. of species common to that period and the present, while the red and coralline crag must be identified,-because their fossils indicate just this same degree of approximation to one another. I apprehend that this is no other than a fair statement of the case, and that I have not pushed analogy beyond reasonable limits; for if we admit, with Mr. Lyell, that the formations of the present day constitute one link of the entire series, and originate in the continued operation of those causes which have been in activity, at least during the deposition of the supracretaceous rocks, we are surely justified in drawing analogous inferences, whether we are comparing the present deposits with the newer members of the tertiary series or the individual members constituting the tertiary group with one another.

* Lyell's Geology, 4th edit,, vol. iv. p. 87. 
Such then was the condition of the inquiry up to the time of a small series of shells from Ramsholt being placed by Mr. Lyell in the hands of M.Deshayes, and the result attending his examination of these fossils has been appealed to as one which must necessarily prove fatal to the views which I entertain as to the relative antiquity of the coralline crag *. A fellowlabourer in the field of geological research, presuming that all other sources of evidence must yield to the deductions arising from a concho-geological investigation, has been led, perhaps rather too precipitately, to exclaim, "If such be the fact, there is an end of the question between my opponent and myself." I trust, however, that without subjecting myself to the imputation of obstinately adhering to preconceived opinions, I shall be able to show that this question is not to be decided by quite so summary a proceeding. A critical examination into the real merits of the per-centage test, as a general rule for determining the comparative ages of tertiary deposits, will be found to exhibit such extensive limits of error in its practical application, that so far as the present inquiry is concerned, I am confident that no impartial observer would feel justified in endeavouring to form a conclusion, either on one sideor the other, from the evidence which has yet been obtained from this source.

Before I proceed to discuss the value which should be attached to certain numerical calculations, I must briefly digress for the purpose of offering a few remarks upon the real nature of the discussion now pending, and its abstract geological importance.

There are doubtless some to whom it may appear a matter of little or no moment, whether we speak of these inferior beds as forming the lower part of the crag formation, so long as that geulogical distinction is made, or whether we consider then altogether as a distinct deposit. Here I would observe, in passing, that there is no $a$ priori reason whatever why a distinct deposit should not be found between the beds called crag and the London clay. In fact, if we adopt Mr. Lyell's present classification of the British and Continental tertiary series, such a discovery would seem to be in every respect a desideratum, for the crag being placed in the pliocene period and the London clay in the eocene, a diposit of an intermediate age would lessen the hiatus between these two formations. Now among some of the important results which have arisen from the accumulated observations of geologists are certain general deductions, involving points of a physiological or general philosophical nature which possess an extreme degree of interest, apart from any connexion with geology as a

* See a paper by Mr. S. Woodward in Lond. and Edinb. Phil. Mag., vol. viii. p. ]39; and also Mr. Lyell's address to the Geological Society, Ibid., p. 32it. 
distinct science. Such are the changes of climate anterior to the historic æra, the comparative duration of species, and the wide geographical range which some extinct organisms enjoyed, having apparently existed at the same period over an immense extent of surface. These and numerous other inferences of a similar kind often depend in a great measure upon the accuracy with which we can refer individual beds or groups of strata to particular deposits, and trace these separate formations in widely remote localities, from observing the occurrence of certain corresponding phænomena. Philosophically speaking, it is, perhaps, of most importance in the fossiliferous rocks to make out the natural subdivisions (if such really exist) of the two extremes of the series; and in arriving at any generalizations analogically deduced from our present insight into the laws of nature, those deposits offer the most legitimate grounds for rational speculation which appear to have originated during an æra that impinges upon the present.

The most novel feature in the organic remains of the crag, considering the whole deposit as referrible to one period, is the occurrence of so many recent mammiferous species in one bed, and so large a series of extinct corals in the other. Now if the coralline crag be older than the stratum in which these mammalian remains are found, we have no longer this association of extinct forms in one class of the animal kingdom with recent types belonging to a very different order. A geologist desirous of instituting a comparison between these tertiary deposits and those in other parts of Europe, might meet with the equivalent of one only, assuming the red and coralline crag to be distinct. It would then become a question of great importance whether the organic remains included in the two series ought to be considered collectively or not, in endeavouring to establish an agreement with the fossils of supposed corresponding strata in distant localities.

Passing to generalizations of a different character, I will select one which I think illustrates in a particularly forcible manner the importance of allowing full play to the present investigation. The occurrence of some extinct mammiferous quadrupeds in deposits containing exclusively or nearly so recent Mollusca, has led Mr. Lyell to attribute a longer duration of species to the latter. Applying this argument to the fossils of the crag, we find conditions of another kind; for the forms which are most widely removed from existing types occur among the corals, while the majority of the mammiferous animals either closely resemble such as are now living, or can be identified with those which are imbedded in the alluvial or lacustrine deposits above the crag. Hence we might infer the short duration of the species of corals when compared with the Mammalia, and consequently the still shorter 
period assigned to their existence if the comparison be drawn between them and Mollusca. In this way erroneous inferences with regard to the comparative duration of species, and other deductions of an equally important nature, might originate solely in an improper identification of the crag beds with one another.

I have made use of the above example as a means of showing how desirable it is that there should, if possible, be a right understanding as to the age of the coralline crag: but at the same time $\mathrm{I}$ would observe that $\mathrm{Mr}$. Lyell's line of reasoning is one which should be applied with the utmost caution; for though it may be quite true that the remains of the mammoth have been found, as at Northcliff in Yorkshire, in conjunction with recent species of Testacea, yet before we can with justice found any argument upon the fact of their occurrence in the same deposit, it is absolutely requisite to show that association is a tolerably conclusive proof of contemporaneous existence : and having settled this point, (which is often no very easy matter, as will be seen in another part of this paper,) we must next inquire whether there be evidence of anterior coexistence during periods of equal duration. The fossil elephant of Yorkshire is found in the red crag, one of the older pliocene deposits; but the recent species of Mollusca with which in one case it was associated are not to be traced back to a period of corresponding antiquity. The duration which we are warranted in assigning to these latter is the time which has elapsed since the formation of the Yorkshire deposit, while we can date the existence of the elephant from the deposition of the red crag up to the period of its subsequent occurrence in the above-mentioned locality.

So far then as the progress of geology is concerned, I think ample reasons exist for prosecuting an inquiry into the relative ages of these tertiary beus; but the attainment of that object through the medium of numerical calculations involves the application of principles, the adaptation of which to the practical purposes of the geologist is an operation complicated in its nature, and which may also be often fallacious in its results.

Mr. Lyell's views upon this subject are so well known and have been so generally received, that without entering upon any detail respecting them, I may at once proceed to discuss the considerations which have led me to distrust the value of the per-centage test in those instances where we require something more than a general approximation towards accurate conclusions*

* Some of the following facts and observations were drawn up as a continuation of a paper on this subject which appeared in the Supplement to the Phil. Mag. for June 1836. The delay in the publication has arisen from my wishing to lay them before the late Meeting of the British Association at Bristol. 
When Professor Agassiz was on a late visit to this country, I was particularly anxious that that distinguished naturalist should bave an opportunity of examining the ichthyological remains of the crag. With this view I endeavoured to obtain as extensive a series of these fossils as possible, and in the course of the summer of 1835 I collected several thousand bones, including vertebræ, teeth, and portions of palates, \&c. A selection from these was submitted to the inspection of M. Agassiz just before he quitted England, and the result of his examination was, that among them he could detect no recent species, and that there were some belonging even to genera extremely remote from any with which he was acquainted. This was a result which $I$ was not prepared to anticipate, as the crag had been classed by M. Deshayes among the pliocene deposits, in consequence of the large proportion of its shells which he had identified with recent species. On a subsequent occasion, however, when M. Agassiz had an opportunity of seeing my entire collection of crag fossils, after expressing great delight and astonishment at the novel structures exhibited by the corals, he mentioned to me his opinion that all the Testacea which he had seen from that formation were extinct. I cannot ven. ture to say what amount of reliance should in this instance be placed on the opinion of Professor Agassiz, but certainly his zoological attainments are by no means confined to that particular department of scientific inquiry in which he has deservedly gained such extensive reputation. The observation thus casually made to me by him was shortly afterwards most unexpectedly confirmed by Dr. Beck of Copenhagen, who appears to have enjoyed very extensive facilities for the study of recent and fossil conchology. Dr. Beck com-. municated to me his opinion of the incorrectness of M. Deshayes' calculation before he had examined my collection, the inspection of which did not occasion any alteration in his views, as may be seen by Mr. Lyell's anniversary address*.

If we now turn to our own country we shall find a most remarkable discordance upon this subject in the opinions of British naturalists, although the balance is certainly not in favour of M. Deshayes. Mr. George B. Sowerby informs me that he has had many opportunities of comparing the crag shells with recent specimens, and that he bas only found two or three shells which may perhaps be identified with living species.

In Professor Phillips's Guide to Geology, we find him placing the crag in the miocene division, probably estimating the proportion of extinct species at about seventy or eighty per cent. I need not here dwell upon Professor Phillips's general accuracy of observation and long familiar acquaintance

* See Lond. and Edinb. Phil. Mag., vol. viii. p. 327. 
with organic remains. I may however mention that there is a large series of crag shells in the museum at York, from the examination of which I believe his opinion has been formed. In justice to $M$. Deshayes, I must now observe that there are several individuals to whose judgement I should be disposed to pay considerable deference, who think that in giving 40 per cent. he has considerably underrated the proportion of recent species, and that more than half, or perhaps three fourths of the crag shells can undoubtedly be identified with species now inhabiting the German Ocean.

The Rev. Dr. Fleming, in a letter to Dr. Mitchell, F.G.S., of London, in alluding to this subject, observes, "Many of the crag species are deep-water species, but I would fearlessly say they are of British origin, and I make the remark, having been an observer and collector of British shells for more than a quarter of a century."

In the annual address delivered by the President to the Fellows of the Geological Society, Mr. Lyell particularly adverts to the discordance of opinion between two such eminent naturalists as Dr. Beck and M. Deshayes, and suggests that it may probably be attributed to their difference of opinion as to the amount of variation necessary to constitute a distinct species. Thus, for instance, Dr. Beck would look upon those six or eight forms which M. Deshayes includes under the name of Lucina divaricata as six or eight distinct species of the genus Lucina, while M. Deshayes would consider them as varieties only. Now this explanation is only admissible upon the assumption that M. Deshayes allows the existence of as much difference between the crag fossils and what he now regards as their living analogues as there is between the six or eight varieties of the Lucina divaricata. This is an important consideration; for if M. Deshayes should assert the identification to be complete between the crag fossils and living shells, it is evident that the explanation offered affords no solution whatever of the difficulty.

From these facts the following inference may, I think, be fairly drawn: that if a series of tertiary fossils be placed before the most eminent conchologists in different countries, for the purpose of ascertaining from the per-centage of extinct species what position in a geological series the formation should hold from which these fossils have been obtained, that position might be decided to be, eocene in Denmark, miocene in England, and pliocene in France; and had we fifty intermediate gradations it is very possible that no two conchologists would refer the deposit in question to the same position.

Greatly as the discordance of these results is to be lamented, as retarding the progress of geology, it must mainly be attributed to the present imperfect condition of conchological sci- 
ence, and not be supposed to invalidate the general course of induction pursued by Mr. Lyell. Nevertheless it must be admitted that the practical application of the principle advocated by this eminent geologist in the classification of the supracretaceous rocks will be extremely limited in operation; for even if we suppose that conchologists universally admit the soundness of the principles upon which the present system of chronological arrangement is founded, they cannot equally make use of it as a means of obtaining numerical relations of affinity, since the characters thought by one to constitute a distinction of species are by another looked upon as mere modinfations of form.

Now, if we entirely throw aside all reference to a per-centage of species, and could substitute in its place a scale of degrees,- - still taking the existing forms as a standard to which the fossil ones are to be referred, but determining the amount of approximation by the totality of the characters which each series exhibits, - we might then, perhaps, justly anticipate an agreement in the conclusions arrived at by different conchologists as to the relative age which should be assigned to any one fossiliferous deposit of the tertiary group; provided, of course, that there be no difference in their respective qualifications for conducting the necessary examination *

Although Dr. Beck asserts that the Testacea of the crag have no existing analogues, thereby necessarily placing that formation in the eocene division of Mr. Lyell, yet as he admits a very considerable degree of resemblance in many of these fossils to species now living in the German Ocean, I apprehend that from that circumstance he would refer this deposit to a much more recent geological æra than the London clay. If I am right in this conjecture, it follows as a necessary consequence that there are two modes by which we estimate the degrees of affinity between fossils of separate deposits, or between fossil and recent species, one being the per-centage test, and the other that which must of necessity be employed by Dr. Beck were he to infer the greater antiquity of the organic remains of the London clay when compared with those of the crag.

Now it can be clearly proved that one of these modes is sometimes fallacious, as there are tertiary deposits to which if both tests be applied results completely at variance with each other will be evolved. Thus many of the forms occurring in the coralline crag are so unlike recent types, that if our estimate of its comparative age were taken from the totality of

- I am proceeding here upon the supposition that there is an uniform approximation to existing species, shown by the fossils of different deposits, corresponding to their respective antiquity. 
the characters which its fossils, considered collectively, present, it would appear much older than the superjacent tertiary beds, but if the numerical test be made use of, the apparent age of both these deposits would be equal. Some remarks by Professor Phillips which have appeared in the Encyclopadia Metropolitana, and which were probably written before 1 had described the conditions under which the organic remains of the crag are deposited, bear very strongly upon the above statement. The passage is as follows: "Upon comparing them [that is, the crag fossils, ] with recent kinds, we are presented with very curious and striking results. There are several of the crag shells so exceedingly similar to recent sbells of the German Ocean that it is impossible to distinguish them. Turbo littoreus retains its colour, many others are with difficulty separated by minute discrimination; but some, as the corals of Orford, Pecten Princeps, Terebratula Dalei, and others, are evidently unlike anything nowe existing in the German Ocean, and indeed not now to be parallcled in any part of the world."-Encyc. Metrop., GEology, p. 674.

Now the Corals, Pecten and Terebratula, spoken of by Professor Phillips as so utterly unlike anything now existing, are fossils of the lower or coralline crag. The Turbo littoreus retaining even its colour, so far as my own experience has gone, occurs only in that bed where we meet with existing species of Mammifera, and the more recent origin of which I have from the first endeavoured to establish.

From what 1 have advanced it will be seen that $I$ am disposed to regard the source of error now under consideration as involved in the application of the per-centage test, and if the history of the crag be ever thoroughly worked out, I think this view will be confirmed. The fallacy probably consists in supposing that by number we can obtain a true expression of relations of affinity, when being totally ignorant of the characters which constitute species, we have really nothing upon which to found our numerical calculations.

I pass on from the consideration of this rather intricate question to another stage of the inquiry; and here for the sake of argument I must assume that there is a general agreement among conchologists as to the characters upon which specific distinctions are founded, and also that the true method of obtaining relations of affinity is the one which has been adopted by $M r$. Lyell and M. Deshayes.

[To be continued.]

Third Series. Vol. 10. No. 58. Jan. 1837. 